\title{
Cost management implementation based on the Balanced Scorecard
}

\author{
Tatiana G. Ryzhakina \\ Department of Management \\ National Research Tomsk Polytechnic University \\ Tomsk, Russia \\ rtg3@mail.ru \\ Evgenia A. Kovaleva \\ Department of Management \\ National Research Tomsk Polytechnic University \\ Tomsk, Russia \\ jennykova@mail.ru
}

\author{
Natalia V. Koroleva \\ Department of Management \\ National Research Tomsk Polytechnic University \\ Tomsk, Russia \\ knv.tpy@mail.ru
}

\begin{abstract}
The problem of raising the value of the machinebuilding enterprises, as the basic industry of the national economy has become vital. The article discusses the implementation of the concept of cost management based on the Balanced Scorecard. Integrating value-based management concept with a balanced scorecard becomes more effective due to the formalization of the strategy of financial and non-financial indicators of enterprise value creation. In the process of implementation of strategy aimed at increasing enterprise value, using balanced scorecard and factor models, enterprise value indicators are forecasted.
\end{abstract}

Keywords - economic value added, cost management concept, balanced scorecard, factor models, value indicators

\section{INTRODUCTION}

The problem of low investment attractiveness remains in the machine-building complex. National machinery currently does not provide necessary reproduction of a competitive economy in Russia. To maintain its market share in the face of increasing competition, engineering companies need to solve a number of problems, namely, to improve the quality of products, to market sophisticated products with new consumer properties, to expand the range of products, etc. The successful solution of these problems can be achieved by increasing the investment attractiveness of enterprises in order to implement innovative programs.

In this regard, there is a need to establish a management system that would effectively support the implementation of the strategy aimed at increasing the value of the enterprise. There is also a need for tools, which allow to manage the implementation process of the strategy and monitor it at all stages of the process. That tool, in our opinion, is the balanced scorecard, adapted to the modern requirements of the market and the specifics of functioning of the enterprises of machinebuilding complex.

\section{ECONOMIC VALUE ADDED OF RUSSIAN ENTERPRISES}

Let us consider the financial activity of the enterprises of mechanical engineering industry in the context of the generated economic value added. To determine the economic value added financial output data for the 2010-2014 period of 16 Russian manufacturing enterprises of mechanical engineering were used.

As the cost of capital, interest rates on loans, which have been estimated at an average annual rate of CBR refinancing rate $(+3) \%$ were used: in $2010-7.75 \%$; $2011-8.25 \%$; 2012 $8.25 \% ; 2013-8.25 \% ; 2014-8.25 \%$. As the cost of equity Federal loan bonds at average rate $(-10 \%)$ was taken. The results (Table. 1) show that, in spite of the positive value of return on assets, the activities of the enterprises of mechanical engineering industry is characterized by a negative value of economic value added, although it should be noted that in 2014, there has been a marked increase in this indicator. The negative value of the economic value added reduces the investment attractiveness of Russian machine-building enterprises, preventing the growth of investments in this sector of the economy, which affects the rate of modernization and innovation.

TABLE I VALUE OF ECONOMIC VALUE ADDED OF MACHINE BUILDING COMPANIES IN RUSSIA

\begin{tabular}{|l|l|l|l|l|l|}
\hline \multicolumn{1}{|c|}{ Indicator } & \multicolumn{1}{|c|}{$\mathbf{2 0 1 0}$} & $\mathbf{2 0 1 1}$ & $\mathbf{2 0 1 2}$ & $\mathbf{2 0 1 3}$ & $\mathbf{2 0 1 4}$ \\
\hline $\begin{array}{l}\text { Return on } \\
\text { Assets, } \\
\text { (ROA), \% }\end{array}$ & 7,4 & 7,6 & 13,3 & 10,2 & 12,6 \\
\hline $\begin{array}{l}\text { Weighted } \\
\text { Average } \\
\text { Cost of }\end{array}$ & 11,1 & 11,2 & 18,6 & 12,2 & 12,3 \\
\hline
\end{tabular}




\begin{tabular}{|l|l|l|l|l|l|}
\hline $\begin{array}{l}\text { Capital, } \\
\text { (WACC), } \\
\%\end{array}$ & & & & & \\
\hline $\begin{array}{l}\text { Economic } \\
\text { Value }\end{array}$ & & & & & \\
$\begin{array}{l}\text { Added, } \\
\text { (EVA), } \\
\text { thousand } \\
\text { rubles. }\end{array}$ & $-52948,2$ & $-5832,8$ & $-49988,0$ & $-18180,0$ & 277,4 \\
\hline
\end{tabular}

III. VALUE BASED MANAGEMENT CONCEPT

In world practice, the concept of value management (VBM) is increasingly popular. VBM concept was originally used by the US large joint-stock companies as the basis of maximizing the value of shares and increasing shareholders value. This management concept assumes that all activities, one way or another should be aimed at increasing its value. Gradually, VBM spread to European businesses, and in recent years began to be used in Russia [1].

The implementation of the value based management concept is based on the determination of financial and nonfinancial indicators of creating enterprise value. You can estimate the value of the entire enterprise and manage its by influencing its factors. Moreover, it is always possible to accurately assess the impact of individual factors on the overall result. Factors should be considered in the system, since they are interconnected and their combined influence on the value may be reinforcing or weakening. Balanced Scorecard in this regard is a powerful tool of identification of financial and non-financial indicators and their target values, affecting the value of the enterprise [2].

\section{IY. BALANCED SCORECARD}

The Balanced Scorecard as the organization's evaluation was developed by Robert Kaplan and David Norton. In the 90s it was offered as a means of overcoming the limitations that arise in the management using only financial indicators. The idea of this system is based on two key provisions [3]:

1. The use in the management of financial indicators alone does not allow to successfully achieve long-term goal of maximizing enterprise value.

2. A well-organized implementation of the chosen strategies is more important than the quality of the strategies themselves.

The Balanced Scorecard has provided enterprise with strategy of value creation mechanism, which is based on four components:

Finance. Strategy of profitability growth and risk management from the perspective of shareholders.

Customers. The strategy of value creation and differentiation from the perspective of consumer needs satisfaction.

Internal business processes. Effective organization of business processes and operational efficiency.
Learning and Growth. The ability of the organization to change, to accept new ideas, flexibility and a focus on continuous improvement.

This balanced system at the same time clearly identifies the factors that create the preconditions for the achievement of organizational goals, tying the effective use of tangible assets with intangible. It becomes an important source of increasing the efficiency and competitiveness.

\section{RESULTS FND DISCUSSIONS}

Current trends in the theory and practice of financial analysis are focused on the problem of the modification of the system of financial indicators. Traditionally, the diagnosis of the financial condition of the company is carried out using a sufficiently large number of indicators. In this regard it is necessary to identify a system of indicators and bring it to a form which would be suitable for objective and timely management decision-making in the process of implementing a strategy focused on enterprise value creation. We have used a statistical approach to the ratio method of financial analysis. The basis for the selection of indicators for the balanced scorecard (BSC) was a system of financial indicators presented V.P.Savchukom [4].The main advantages of this system are that it provides: 1) financial evaluation of the enterprise based on its financial statements: balance sheet, income statement, cash flow statement; 2) selection and grouping of indicators according to the main areas of activity of the enterprise. The following perspectives of BSC were chosen: "Finance", "Customers", "Processes", "Potential". The perspective of "potential" in the BSC enables to incorporate both existing and future potential of the company.

Outlining perspectives for BSC model, indicators were selected using the following main criteria: the degree of influence on value creation, the possibility of quantitative measurement, accessibility, clarity, balance, relevance, unambiguous interpretation, as well as the presence of causeand-effect relationships between indicators.

As the information base data from the output of financial documents in 2012-2014 machine building factories [Authors' calculations] were used. Also the results of correlation between the financial performance indicators of balances at the beginning of 1998, uniting more than 500 thousand Russian enterprises of basic sectors of the economy were taken into account [5].

The correlation coefficients with values from 0.5 to 0.7 , and especially less than 0.3 characterize weak relationship and, therefore, have great significance and informative value. Therefore, it is advisable to select for BSC indicators with low correlation between them. It is necessary to clarify that we are talking about indicators that characterize the same aspects of the financial condition of the enterprise in the implementation of its strategy of value creation. At the same time, the high correlation between the selected BSC financial and nonfinancial indicators (correlation coefficient greater than 0.7) is 
important, as it allows to see how meaningful impact on one indicator will be reflected in the value of other [6].

As a result of the correlation analysis, and taking into account the above requirements for BSC indicators, the following indicators were selected.

\section{PERSPECTIVE “FINANCE”:}

1) Return on assets estimates the effectiveness of the use of assets (ROA);

2) Net profit ratio shows the share of net income in sales (KNP);

3) Rate of change of gross sales - is a quantitative characteristic of the sales volume growth in the current period in relation to the gross sales of the previous year (KGS);

4) Ratio of the production cost of goods sold shows the share of production costs in the revenue from sales (KCoGS).

The relationship between ROA and KNP characterized by equation (1):

$$
\mathrm{ROA}=0,057+0,625 K_{N P}
$$

The coefficient of determination $R^{2}-0.982$, indicates the close relationship of these indicators. Substituting the known values $K_{N P}$. You can predict changes in $R O A$ values (Table. 2).

TABLE II CORRELATION AND REGRESSION ANALYSIS OF ROA AND KNP

\begin{tabular}{|l|c|c|c|c|c|c|}
\hline \multirow{2}{*}{ Indicator } & \multicolumn{3}{|c|}{ Actual Values } & \multicolumn{3}{c|}{ Forecasted Values } \\
\cline { 2 - 7 } & 2012 & 2013 & 2014 & 1 year & 2 year & 3 year \\
\hline$R O A$ & 0.133 & 0.102 & 0.126 & 0.160 & 0.170 & 0.180 \\
\hline$K_{N P .}$ & 0.121 & 0.071 & 0.110 & 0.165 & 0.181 & 0.197 \\
\hline
\end{tabular}

Source: Authors' calculations

The relationship between the three factors $\left(K_{N P}, K_{C o G S}\right.$ and $\left.K_{G S}\right)$ is represented as a multiple regression equation (2):

$$
K_{N P}=0.436-0.401 K_{C o G S}+0.0283 K_{G S}
$$

The coefficient of determination $R^{2}-0.912$, indicates a close relationship between $K_{N P}$ and $K_{C o G S}$ and the coefficient of determination $R^{2}$, equal to 0.914 , indicates a close relationship between $K_{N P}$ and $K_{G S}$. Substituting the known values $K_{C o G S}$ and $K_{G S}$ can predict changes in values of $K_{N P}$. (Table. 3).

TABLE III CORRELATION AND REGRESSION ANALYSIS KNP, KCOGS AND KGS

\begin{tabular}{|l|l|l|l|l|l|l|}
\hline \multirow{2}{*}{ Indicator } & \multicolumn{4}{|c|}{ Actual Values } & \multicolumn{3}{|c|}{ Forecasted Values } \\
\cline { 2 - 7 } & 2012 & 2013 & 2014 & 1 year & 2 year & 3 year \\
\hline $\mathrm{K}_{\mathrm{NP}}$ & 0.119 & 0.102 & 0.118 & 0.165 & 0.181 & 0.197 \\
\hline $\mathrm{K}_{\mathrm{CoGS}}$ & 0.810 & 0.850 & 0.812 & 0.693 & 0.656 & 0.618 \\
\hline $\mathrm{K}_{\mathrm{GS}}$ & 0.301 & 0.252 & 0.299 & 0.250 & 0.280 & 0.310 \\
\hline
\end{tabular}

Source: Authors' calculations

\section{PERSPECTIVE “CLIENTS”:}

Within this perspective, the following indicators have been selected.

1) Asset turnover ratio shows how many times company's assets turn themselves over into sales over a given period (year) (AT);

2) Accounts receivable turnover ratio shows how many times receivables turn themselves over into sales over a given period of time (ART);

3) Share of sales to regular customers characterizes the stability of the enterprise customer base (PRC);

4) Market share illustrates the success of the enterprise in the market (MS);

5) Share of sales with no deviations in the supply terms (SnDS).

The next step - prediction of performance indicators based on past experience and set corporate goal of the enterprise.

The relationship between ART and ATis characterized by the equation (3):

$$
A T=0.6716+0.0893 A R T
$$

The coefficient of determination $R^{2}-0.974$, indicates close relationship of these indicators. Substituting the known values of the ARTcan predict changes ATvalues (Table. 4).

TABLE IV CORRELATION AND REGRESSION ANALYSIS OF ART AND AT

\begin{tabular}{|l|l|l|l|l|l|l|}
\hline \multirow{2}{*}{ Indicator } & \multicolumn{3}{|l|}{ Actual Values } & \multicolumn{3}{|c|}{ Forecasted Values } \\
\cline { 2 - 7 } & 2012 & 2013 & 2014 & 1 year & 2 year & 3 year \\
\hline$A T$ & 0,972 & 0,946 & 0,963 & 1,565 & 2,011 & 2,279 \\
\hline$A R T$ & 3,369 & 3,071 & 3,267 & 10,0 & 15,0 & 18,0 \\
\hline
\end{tabular}

Source: Authors' calculations

\section{PERSPECTIVE "PROCESSES”.}

Within this perspective the following indicators have been selected.

1) Profitability characterizes cost recovery in production activity (PPR);

2) Inventory turnover ratio shows how many times inventories turn over into cost of goods manufactured over a period of time (IT);

3) Share of new products in total output (NPS);

4) Capital productivity shows the efficiency of assets use (CP).

The relationship between the $A T$ and $I T$ is characterized by equation (4):

$$
A T=0.4821+0.0310 I T
$$


The coefficient of determination $R^{2}-0.956$, indicates the close relationship of these indicators. Substituting the known values $I T$, you can predict changes $I T A T$ values. (Table. 5).

TABLE V CORRELATION AND REGRESSION ANALYSIS AT AND IT

\begin{tabular}{|l|l|l|l|l|l|l|}
\hline Indicator & \multicolumn{3}{|c|}{ Actual Values } & \multicolumn{3}{c|}{ Forecasted Values } \\
\cline { 2 - 7 } & 2012 & 2013 & 2014 & 1 year & 2 year & 3 year \\
\hline$A T$ & 0.972 & 0.946 & 0.963 & 1.565 & 2.011 & 2.279 \\
\hline$I T$ & 15.803 & 14.965 & 15.513 & 34.932 & 49.312 & 57.965 \\
\hline
\end{tabular}

Source: Authors' calculations

Relationship between $K_{C o G S}$. and $C P$ is characterized by equation (5):

$$
K_{C o G S .}=0.9380-0.0128 C P
$$

The coefficient of determination $R^{2}-0.982$, indicates the close relationship of these indicators. Substituting the known values of $C P$, you can predict changes in $K_{C o G S}$ values. (Table. $6)$.

TABLE VI CORRELATION AND REGRESSION ANALYSIS KCOGS. AND CP

\begin{tabular}{|l|l|l|l|l|l|l|}
\hline Indicator & \multicolumn{3}{|l|}{ Actual Values } & \multicolumn{3}{|c|}{ Forecasted Values } \\
\cline { 2 - 7 } & 2012 & 2013 & 2014 & 1 year & 2 year & 3 year \\
\hline$K_{C O G S}$ & 0.810 & 0.850 & 0.815 & 0.693 & 0.656 & 0.618 \\
\hline$C P$ & 10.0 & 6.875 & 9.609 & 19.141 & 22.031 & 25.0 \\
\hline
\end{tabular}

Source: Authors' calculations

\section{PERSPECTIVE “POTENTIAL”:}

1) Stability of staff (KST);

2) Portion of staff, undergone special training shows what proportion of the staff meets the required professional qualifications (KTR);

3) Portion of staff with strategic competencies (KStC) defines the share of personnel motivated to meet strategic business objectives.

Thus, based on the conducted correlation and regression analyzes and developed factor models, forecasted indicators of enterprise value in the implementation of business strategy are presented (Table. 7).

\section{TABLE VII FORECASTED INDICATORS OF VALUE}

\begin{tabular}{|c|c|c|c|}
\hline Indicator & 1 year & 2 year & 3 year \\
\hline Return on Assets, ROA, \% & 16.0 & 17.0 & 18.0 \\
\hline Net profit ratio, $K_{N P}$ & 0.165 & 0.181 & 0.197 \\
\hline $\begin{array}{c}\text { Rate of change of gross } \\
\text { sales, } K_{G S}\end{array}$ & 0.250 & 0.280 & 0.310 \\
\hline $\begin{array}{c}\text { Ratio of the production } \\
\text { cost of goods sold, } K_{C o G S}\end{array}$ & 0.693 & 0.656 & 0.618 \\
\hline Asset turnover, AT, cycles & 1.565 & 2.011 & 2.279 \\
\hline $\begin{array}{c}\text { Accounts receivable } \\
\text { turnover, ART, cycles }\end{array}$ & 10 & 15 & 18 \\
\hline $\begin{array}{c}\text { Share of sales to regular } \\
\text { customers, } P_{R C}\end{array}$ & 0.6 & 0.7 & 0.8 \\
\hline $\begin{array}{c}\text { Market Share, MS } \\
\text { Share of sales with no } \\
\text { deviations in the supply }\end{array}$ & 0.54 & 0.55 & 0.56 \\
\hline
\end{tabular}

\begin{tabular}{|c|c|c|c|}
\hline terms, $P_{S n D}$ & & & \\
\hline $\begin{array}{c}\text { Profitability of production, } \\
P_{P R}, \%\end{array}$ & 21.3 & 25.5 & 30.8 \\
\hline $\begin{array}{c}\text { Inventory turnover, IT, } \\
\text { cycles }\end{array}$ & 34.932 & 49.312 & 57.965 \\
\hline $\begin{array}{c}\text { Share of new products in } \\
\text { total output, NPS }\end{array}$ & 0.5 & 0.6 & 0.65 \\
\hline $\begin{array}{c}\text { Capital Productivity, } C P \\
\text { rub./ rub. }\end{array}$ & 19.141 & 22.031 & 25.0 \\
\hline Stability of staff, $K_{S T}$ & 0.7 & 0.81 & 0.95 \\
\hline $\begin{array}{c}\text { Portion of staff, undergone } \\
\text { special training, } K_{T R}\end{array}$ & 0.76 & 0.85 & 1.0 \\
\hline $\begin{array}{c}\text { Portion of staff with } \\
\text { strategic competencies, } \\
K_{S t C}\end{array}$ & 0.82 & 0.91 & 1.0 \\
\hline
\end{tabular}

Source: Authors' calculations

\section{CONCLUSION}

BSC allowed enterprises first adopted it orienting and concentrating administration, business-units, staff, information technology and financial resources to perform the strategy. It offers a model to help to formulate a value creation strategy and bring it to each employee's attention by the most available and sequential means. Strategy, as well as the architecture of processes necessary for performance of this strategy is determined within a strategic management system.

The approved strategic objectives are developed up to the level of processes by decomposition of objectives and indicators. At the upper levels of management the target values of indicators are set in the framework of a strategic planning system.

So, as a result of integration with the Balanced Scorecard the concept of focus enterprise value becomes more effective due to:

1) formalization of strategy by use of Balanced Scorecard of enterprise value on strategic and operational planning levels;

2) dissemination of strategy at all levels of the enterprise in the process of cascading of BSC on all structural subdivisions;

3) possibility of management of strategy realization process at all levels;

4) the use of non-financial indicators in the BSC, which are also involved in the creation of enterprise value.

\section{References}

[1] O. P. Ivanova, I. S. Antonova, G. D. Antonov, Company towns development and investment attractiveness: Moscow, INFRA-M, 2016.

[2] I. S. Antonova, O. A. Negodina, D. D. Vavilov "Russian company town: creteria and diversification results", IBIMA 2015, pp. 2181-2187, November 2015.

[3] R. Kaplan., D. Norton, Strategy maps. Transformation of intangible assets into tangible results. M.: Marseille - Business, 2010.

[4] V.P. Savchuk, Enterprise Diagnostics: support management decisions. M.: Binom. Knowledge Laboratory, 2010.

[5] E. V. Lisitsyn, "The statistical approach to the coefficient method in the rapid analysis of enterprise", Financial Management 2001: pp 17-19, january 2001. 
[6] T. G. Ryzhakina, Integrated planning tools in the implementation strategy of the enterprise. Tomsk: Publishing house TPU, 2013. 